\title{
SERVICE-LEARNING IN NURSING: INTEGRATING STUDENT LEARNING AND COMMU- NITY-BASED SERVICE EXPERIENCE THROUGH REFLECTIVE PRACTICE
}

\section{Hester Julie}

M Public Health, University of the Western Cape

Senior Lecturer, Department of Nursing, University of the Western Cape

Corresponding author: hjulie@uwc.ac.za

\section{Priscilla Daniels}

MSc, University of Cornell, USA

Associate Professor and Research Coordinator of the Community Higher Education Services Partnership Programme, University of the Western Cape

\section{Tracey-Ann Adonis}

MA Research Psychology, University of the Western Cape

Academic Coordinator of the Community Higher Education Services Partnership Programme, University of the Western Cape

Keywords: gender-based violence; community-based service; service-learning; reflective practice; civic engagement

\section{ABSTRACT}

Domestic violence is a pervasive problem in South Africa. The School of Nursing at the University of the Western Cape has responded to the challenge of training sensitive, knowledgeable and skilled health personnel by developing a Management of Gender-Based Violence (GBV) module. The purpose of this paper is to describe the professional and personal development of nursing students in this programme through their service-learning experience in the GBV module based on the analysis of the description of the students' reflective journals, group project reports and a focus-group discussion as the primary data sources. Analysis showed that students gained critical thinking skills and developed an understanding of the supportive role health professionals can play through developing skills of caring, advocacy and a commitment to civic engagement, which promotes collaborative relationships. Some of the lessons learnt from this experience include realistic planning in terms of outcomes, time frames, and available resources as well ensuring support from colleagues for the effective implementation of the programme.

\section{OPSOMMING}

Huishoudelike geweld is 'n wydverspreide probleem in Suid-Afrika. Die Departement Verpleegkunde van die Universiteit van Wes-Kaapland het die uitdaging vir die ontwerp van 'n module oor die hantering van Geslagsgegronde Geweld (GGG) vir die opleiding van sensitiewe, kundige en vaardige gesondheidspersoneel aanvaar. Die doel van hierdie artikel is om die professionele en persoonlike ontwikkeling van verpleegstudente in hierdie program op grond van hulle diensleweringservaring te beskryf. Hierdie uiteensetting is gebaseer op die ontleding van die beskrywings van die studente se reflektiewe joernale en 'n fokusgroepbespreking, en dui aan dat studente kritiese denkvaardighede aangeleer het, begrip ontwikkel het ten opsigte van die ondersteunende rol wat professionele gesondheidspersoneel kan speel deur die ontwikkeling van vaardighede soos omgee en voorspraak, en dat hulle 'n verbintenis tot siviele interaksie samewerkingsverhoudings sal bevorder. Van die lesse wat uit hierdie ervaring geleer is, sluit in realistiese beplanning ten opsigte van doelwitte, tydskedules, beskikbare bronne sowel as versekering van die ondersteuning van kollegas vir die effektiewe implementering van die program. 


\section{INTRODUCTION}

The management of gender-based violence (GBV) is a contentious public health issue in South Africa. Domestic violence, one form of GBV, is described as a pervasive problem in South Africa, which is underreported and inadequately diagnosed by nurses and other health professionals (Nudelman \& Trias, 1999:9; Limandri \& Tilden, 1996:247) although the impact of domestic violence on the health of women has been well researched (Heise, Ellsberg \& Gottemoellet, 1999:18).

The latest statistics on femicide released in South Africa show that a woman is killed by her intimate partner in South Africa every six hours (Matthews, Abrahams, Martin, Vetten, Van der Merwe \& Jewkes, 2004:1). These statistics highlight the extent of the problem and suggest that initiatives should be introduced to address this problem especially, because public health services are often the point of first and only contact for abused women. Health workers can identify abuse and intervene at an early stage, as abused women often interact with the health care system for routine or emergency care before turning to criminal justice or domestic violence services (Kernic, Wolf \& Holt, 2000:416).

Research indicates that many health professionals fail to intervene in GBV in spite of strong suspicion of abuse and objective guidelines with regard to the identification of abuse (Campbell, Pliska, Taylor \& Sheradin, 1994:280; Williams, 1995:1488). The health sector therefore has a critical role to play in addressing the needs of survivors of GBV. Alternative teaching methodologies will be necessary because simply addressing the content area of GBV is insufficient. What is needed is ethical reasoning with case analyses and probably the most useful and impressive method would be to provide clinical experience in such organisations as an abused women's shelter (Limandri \& Tilden, 1996:252).

In light of this, the School of Nursing (SON) of the Faculty of Community Health Sciences at the University of the Western Cape (UWC) developed and implemented a service-learning module on the management of GBV for the fourth-year undergraduate students (funded by the Community Higher Education Services Partnership
Programme - CHESP) that involves continuous clinical placement for five months at the Saartjie Baartman Centre for Abused Women and Children (The Centre) in Athlone, Cape Town. Higher education institutions face enormous challenges in preparing graduates to function effectively as professionals in a rapid changing health care system and there has been a growing interest in Service Learning (SL). UWC, likewise, has been involved in the Joint Education Trust-funded CHESP project since 2001 with the view of institutionalising Service Learning (Daniels \& Adonis, 2004:3).

\section{PROBLEM STATEMENT}

Proponents of Service Learning generally claim that exposure to SL projects allow students to cultivate critical thinking skills, social understanding and civic participation (Eyler \& Giles, 1999:12; Jacoby, 1999:9). "Far from denying the value of more traditional pedagogical strategies - including the basic lecture/ discussion - it transforms and renews the educational enterprise as a whole - by linking the classroom to the world of praxis, it allows induction to complement deduction, personal discovery to challenge perceived truths, immediate experience to balance generalisations and abstract theory" (Zlotkowski, 1998:3). Service Learning as a teaching methodology therefore provides nursing students with opportunities to develop both the core values of professional nursing (American Association of Colleges of Nursing, 1998) and their competencies through modelling these professional values, while meeting community needs and contributing to the greater need of society in the process (Levy \& Lehna, 2002:220). While students are expected to perform their professional duties, they perform activities beyond the scope of the curriculum and duty thus enabling them to develop an attitude of civic engagement. In addition, service-learning provides an opportunity for the students to reflect on the service activity in such a way as to gain further understanding of the course content, a broader appreciation of the discipline and an enhanced sense of civic responsibility. This is achieved through the introduction of reflection as an assessment strategy. Reflection has been identified as a foundational principle of SL and is regarded as the glue that holds service and learning together to provide optimal educative experience (Eyler \& Giles, 1996:10). Reflective practice is about acquiring the skills and attitude to inquire continually into own professional practice and 
into the context in which it is embedded. SL therefore provides higher education institutions with a strategy to explore ways of incorporating service to extend their mission, enhance student achievement and engage students in their communities as part of their academic curriculum (Bringle \& Hatcher, 1995:112)

There is a paucity in documented evidence on research in SL according to Sternas, O'Hare, Lehman and Milligan (1999:67) and Sedlack, O'Doheny, Panthofer and Anaya (2003:100) and it is therefore imperative that the findings of this GBV module contribute to the growing research base on SL in the South African context (Julie, 2005:3). The purpose of this study was therefore to gain a deeper understanding of the experiences of the students who were involved in the trial run of the GBV service-learning module, and to report on these in order to contribute to the growing knowledge base of research in SL and the usefulness of this teaching methodology. The research question therefore assesses the professional and personal development of students, which occurred during the service-learning experiences in this Management of Gender-Based Violence module, as reflected in the students' group project reports, reflective journals, exit student focus group and the researcher's field notes as participant observer (Julie, 2003:9).

Since the aim of the CHESP project at UWC is to establish criteria for developing best practice in SL (Daniels \& Adonis, 2004:3), the first objective was to determine whether students achieved the objectives identified in the course outlines. The second objective was to determine how the SL experience contributed to students' professional and personal development. The latter objective was to identify factors, which either contributed to or impeded the achievement of the above objectives.

\section{LITERATURE REVIEW}

The background contextualises GBV as a public health issue and the national need to train appropriately skilled health professionals. The service-learning model as a teaching methodology is discussed, following that; and lastly the conceptualisation process of the CHESP service-learning course of the GBV module in the School of Nursing at the UWC is described.

\section{Definition of GBV}

The United Nations defines violence against women (VAW) as: "Any act of gender-based violence that results in, or is likely to result in, physical, sexual or psychological harm or suffering to women, including threats of such acts, coercion or arbitrary deprivations of liberty, whether occurring in public or private life" (United Nations General Assembly, 1993:444).

VAW is often referred to as "gender-based" violence because it evolves in part from women's subordinate status in society (Heise, Ellsberg \& Gottemoellet, 1999:1). Gender-based violence is understood as violence directed against women as a manifestation of unequal power relations between men and women. It is also considered to be a pattern of coercive, learned behaviour that is used to maintain power and control in a relationship, and it constitutes a serious threat to the health and life of women (Hayward \& Weber, 2003:5).

Kistner's operational framework, which states that the term GBV is not synonymous with VAW is adopted because: "The analyses of 'gender-based violence' recognize that violence directed against a person on the basis of his or her gendered identity is not directed at women and girls only. Some of the same mechanisms that entrap girls and women in subordinate roles keep men and boys entrapped in masculinist identifications that are being played out in abusive ways. Nevertheless, these mechanisms produce gender-differential effects" (Kistner, 2003:12).

\section{GBV as a public health issue}

GBV is a significant public health issue in both developed and developing countries and research is beginning to offer a global overview of the extent of VAW. Worldwide, studies indicate that intimate male partners have beaten between $20-50 \%$ of women. In the United States of America (USA), approximately a third of women patients in emergency departments' injuries are due to domestic violence (Watts \& Zimmerman, 2002). South African prevalence studies indicate that between $19-28 \%$ of women have been physically abused, whilst $49 \%$ of female patients attending a Cape Town community health centre, had a history of domestic violence. A study of male municipal workers showed that $43 \%$ of the men reported that they have physically abused a partner in the last 10 years (Abrahams, Jewkes \& Laubsher, 1999:5; Heise, 
Raikes, Watts \& Zwi, 1994:1165).

VAW has been put on the global policy agenda, especially as a human rights and health issue. Evidence of growing international concern over VAW is reflected in the Pan American Treaty Against Violence Against Women, the World Bank's report entitled VAW, the Hidden Health Burden and the General Assembly of the Declaration by the United Nations calling on all member states to pursue by all appropriate means and without delay a policy of eliminating VAW (Heise et al. 1994:1172).

\section{National need to train health profession- als skilled in the management of GBV}

The White Paper for the Transformation of the Health System in South Africa identifies violence as a "priority problem", and the section on mental health allocates three responsibilities to the National Department of Health, namely the development and promotion of specific programmes addressing abuse of women and children; the management of victims of violence with the aim of improving counselling services; and the management of victims of attempted suicide, violence and rape in Africa (Department of National Health, 1997).

The Higher Education White Paper (1997) emphasises the following goals: "... social responsibility and awareness amongst students of the role of higher education in social and economic development through community service programmes"; producing skilled graduates who are competent in critical, analytical and communication skills to deal with change, diversity and tolerance to opposing views (Reddy, 2004:38).

Domestic violence remains a pervasive problem in South Africa in spite of the above-mentioned responsibilities. The most recent statistics indicates that a woman is killed by her intimate partner in South Africa every six hours (Matthews, Abrahams, Martin, Vetten, Van der Merwe \& Jewkes, 2004:1). These statistics certainly highlight the magnitude of the problem and suggest that initiatives should be introduced to address the problem, yet domestic violence is underreported and inadequately diagnosed by nurses and other health professionals (Nudelman \& Trias, 1999:9).

The Department of National Health, the Women's Health and Genetics Directorate and the Gender Focal Point responded to this challenge by co-hosting a workshop with the South African Gender-Based Violence and Health Initiative (SAGBVHI) in March 2001, to initiate a process of developing an appropriate response to GBV by the health sector. This workshop identified both inservice training and the integration of GBV into the curriculum of universities and colleges as priorities. Subsequently, the Department of National Health also expressed the need to train sensitive, appropriately skilled and knowledgeable health professionals to deal with this pervasive problem. Limandri and Tilden (1996:47) are of the opinion that "Detection and treatment of family violence cannot be significantly improved until factors that deter health professionals from detecting and intervening are understood".

Transformation in South Africa has impacted on the workplace resulting in a constant process of change, and professional training should therefore prepare students to work within this dynamic environment. It is essential for health professionals to develop the ability to improvise and utilise their initiative in real situations where resources are minimal. Students should also be able to facilitate change and to exercise flexibility in their management of changing situations. Alternative teaching methodologies would therefore need to be introduced in order to address this problem at the higher education institution level.

\section{SERVICE-LEARNING IN NURSING}

Service-learning combines community-based service with student-learning, and it is the opinion of the authors that this teaching method would assist in training health professionals who would display caring attributes and civic engagement. Bringle and Hatcher (1995:112) define service-learning as a credit-bearing educational experience in which students participate in an organised service activity that meets identified community needs. These experiences provide a connection between the students' studies and the real world in a way that would not be otherwise achieved.

The underlying philosophy of service-learning is the development of partnerships. A partnership between a community-based non-profit organisation that provides comprehensive services to survivors of domestic violence affords the undergraduate nursing students the 
opportunity to gain valuable interdisciplinary experience in responding to such survivors (Hayward \& Weber, 2003:6). These authors assert that nurses working in partnership with other key role-players are in a position to intervene effectively within the health care system in cases of GBV, particularly if equipped with the necessary skills and knowledge during their educational training. In the light of this, the SON at the UWC developed and implemented a service-learning course for fourthyear undergraduate students.

\section{CONCEPTUALISING THE CHESP SERV- ICE-LEARNING COURSE}

The GBV curricula were developed in consultation with key role-players in the field of GBV locally, nationally and internationally (Julie, 2003) since the aim of the CHESP project at UWC is to establish criteria for developing best practice in SL (Daniels \& Adonis, 2004:3).

The Centre, the community-training site for the piloting of the service-learning module was established during 1998 as the first one-stop service centre for abused women in the country. The partnership was formed so that the SON could assist in running an essential medical service at the Centre in order to ensure that women and children have a one-stop service. The external evaluation report of the Centre states: "The results of the evaluation reveal that the services provided by the Centre are of good quality, relevant to local needs and [have] had a positive impact on the reduction of violence, healing of victims, and empowerment (skills training and job creation) of its clients" (Els, 2002:7).

This perfectly matched the training needs of the Department of Nursing at UWC, as the aims of the GBV modules were to:

- develop skills/competencies in health professionals, in order to provide effective, comprehensive and quality care to survivors of gender-based violence;

- to assist health professionals to function effectively, within a comprehensive health service, as a member of the multidisciplinary team that provides holistic preventative, promotive and curative management of the common conditions/illnesses presenting at a primary level of care;

- develop the personal and interpersonal skills of health professionals through collaborative efforts;

- develop critical thinking in health professionals; and
- develop civic engagement in health professionals (Management of GBV Module Descriptor, 2003:1).

According to Weigert (1998:5), the prescribed curriculum, which flows out from and back into the programme's objectives, determines the services provided by the students. These objectives are integrated into the programme by means of assignments that require reflection on the students' service, based on these course objectives. Wellington and Austin (1996:307-316) suggest five orientations to reflective practice, namely immediate (emphasises pleasant survival, which results in eclectic shallow activities and recipes), technical (focuses on the development and perfection of instructional methodologies), deliberative orientation (places emphasis on the discovery, assignment and assessment of personal meaning), dialectic orientation (advocated political liberation) and transpersonal orientation (centres on universal personal liberation). Reflective experiences provide a connection between the students' studies and the real world in a way that is difficult to achieve through classroom lecture. The purpose of the present study is to describe the professional and personal development of nursing students involved in this programme through their service-learning experience in the CHESP Management of Gender-Based Violence programme.

\section{RESEARCH DESIGN AND METHOD}

A qualitative, contextual and descriptive design was used to provide rich information from in-depth descriptions of students' perceptions and experiences with regard to the service-learning module (Mouton, 1996:103). The design is exploratory because it tried to explore the richness and complexities imbedded as mentioned above. The study is also contextualised within the changing South African Higher Education landscape and the descriptive significance is imbedded in the engagement with current academic debates around the use of SL as an appropriate pedagogy in training health professionals that are responsive to societal needs. The phenomenological design was deemed the most appropriate to obtain the necessary information because the researcher tried to identify what was significant in the lives of the students in terms of personal and professional development based on the students' "critical reflections" about their service-learning experience with the view of making alterations to 
the GBV programme (Brink, 1996:119; Crabtree \& Miller, 1992:24). This phenomenological approach enabled the researcher to examine and explain problems and events from the perspectives of participants namely their experiences, understandings and interpretation of events (Crabtree \& Miller, 1992:24).

\section{Population and sampling}

Qualitative studies typically focus in depth on relatively small samples selected purposefully because it is concerned with information richness and not representativeness (Patton, 1990:23). The study population was the fourth-year Baccalaureate Curationis students, registered for the module Management of Gender Based Violence in 2003, within the SON, which is located within the Faculty of Community and Health Sciences at the University of the Western Cape. Purposive sampling was used because the key informants, 29 female students involved in the pilot run of the module, were selected to "illuminate" the research question (Brink, 1996:141). Male students were excluded because of the Centre's policy. The students were given a choice about whether to participate or not and were ensured that anonymity and confidentiality would be maintained, as they were not required to identify themselves.

\section{Data collection}

The researcher used multiple sources of information in pursuing methodological triangulation to corroborate and substantiate the findings (Merriam, 1998:96). The group project reports contained the following information: the group's learning objectives specifying the workplan, reflection as to why objectives were not attained, exploration and intervention strategies for achieving those objectives. Students were also expected to record the outcomes of these objectives as these allowed students to monitor their progress and ensure continuity of the project (Julie, 2003:7). These group reports were submitted weekly to the researcher. The individual reflective journals were also submitted weekly to the researcher but students were given the guarantee that data from this source will not be included in the research report without their permission. This created a safe space where students could honestly and without feelings of intimidation express their experience, which allowed the researcher to monitor the effects of the clinical experiences on the students' mental health.

\section{Focus group}

Three fourth-year students, purposively selected and trained by the researcher as research assistants, conducted the focus group interview during November 2003 at the Centre using the standardised CHESP student focus-group protocol (Julie, 2005:28). Utilising the students as facilitators was essential to the success of this data-collection method because it allowed students the freedom to respond in an unrestricted manner. One student facilitated the group, whilst the other two operated the tape-recorder and made notes. The 27 female students participated in the focus-group discussion until saturation was reached within approximately $90 \mathrm{~min}$ utes. The topic for discussion was decided upon in advance, but the sequence and wording of the questions were flexible. The focus-group discussion was introduced by this open-ended research statement: "We want to learn more about how you felt about your service-learning experience at the Saartjie Baartman Centre and will ask you a few questions that will focus on aspects of the experience and its effect on you as a student".

This statement was supported by probing and clarifying questions like:

- Did you find that this course was different to other courses that do not have a service-learning component? Explain your viewpoint.

- What kinds of activities were you involved in during the course (especially in relation to working with the community and service provider)? Is this what you expected?

- What did you learn from this experience about the community in which you worked?

The researcher tried to identify the factors that have impeded or enhanced the curriculum development process as well as the strategies employed by students to overcome identified impediments.

Participant observation is an effective technique to gather qualitative data as Leedy (1997:161) states that researchers' "deep personal interest in their topics" is characteristic of this approach. The researcher's deep personal interest stemmed from her involvement as the GBV curriculum designer, as CHESP SL course convenor, and as lecturer seeking feedback from the trial run of the GBV curriculum. The researcher kept field notes using the CHESP Faculty Focus-Group frame- 
work during the once-a-week clinical accompaniment sessions to the site, the weekly hourly plenary reflective sessions on campus, and by means of the weekly analysis of the group project reports and the reflective journals. This technique was very crucial in terms of giving feedback and monitoring the morale and progress of the students (Julie, 2005:27). The researcher tried to minimise observer bias by disclosing preconceptions and assumptions that may have influenced the data collection and the processing thereof.

\section{Data analysis}

Data analysis is the process of bringing order, structure and meaning to the mass of collected data. This is done by organising the data, generating categories, themes and patterns, testing the emergent hypotheses against the data, searching for alternative explanations and writing the report (Marshall \& Rossman, 1989:114). The data were analysed in accordance with the conceptual framework provided by CHESP (Mouton, Wildschut \& Boshoff, 2004:1) and the framework by Eyler and Giles (1999) which identifies five possible cognitive and affective factors that determine the success of service-learning programmes, namely personal and interpersonal development, understanding and application of subject matter, critical thinking, perspective transformation, citizenship skills and values.

The Educational Research Agency acted as independent coder because they used the primary data from the CHESP Narrative Reports to do a comparative analysis (Mouton, Wildschut \& Boshoff, 2004:1). The researcher used the following steps:

- The focus group was audio taped and transcribed verbatim as soon as possible by the research assistants.

- "In vivo" codes were developed by using words and phrases of the informants in the research report (Strauss \& Corbin, 1990:105).

- Focusing on "meaning units" developed themes and patterns, namely the smallest segment of text that was meaningful by itself (Leedy, 1997:162) as opposed to developing categories during the exploding (preliminary analysis) of the data.

- Categorising data means grouping together concepts that seem related to the same phenomena and giving it a conceptual name
(Strauss \& Corbin, 1990:24).

Content analysis of the interviews were done to identify any additional patterns not evident from the initial analysis and also to identify possible redefinitions of domains and operational principles.

\section{Trustworthiness}

Merriam (1998:204) proposes six strategies to enhance internal validity: triangulation, member checks, longterm observation, peer examination, participatory or collaborative modes of research, and researcher biases. Within the study, the following strategies were used: Triangulation, which refers to the use of multiple data collection methods from divergent data sources, and here the researcher used active participant observation field notes, reflective journals, the group reports and the student focus group to confirm the emergent findings (Merriam, 1998:204). A literature review was undertaken to clarify the different concepts prior and during to the analysis phase of the study ensuring triangulation of primary and secondary sources. Member checks from the Director and the Manager of the Centre, and the three student researchers who were all signatories to the Narrative Report and the ERA, acted as independent coders to ensure the credibility and plausibility of the findings (Julie, 2003:1). Researcher bias was disclosed by stating the researcher's theoretical orientation and her interest in the study at the beginning. Participatory research was used, in that three students were purposively selected and trained from the SL cohort to conduct the focus group using the CHESP Student Focus-Group Protocol (Julie, 2005:28).

The following strategies were used to ensure external validity, namely clarifying the investigator's position, an audit trail and triangulation. Thick descriptions of information have been provided (Merriam, 1998:211) to facilitate the process of assessing the potential for transferability and appropriateness for readers. Thick description is defined as a "detailed account of the context and the subjects of the study" (Crabtree \& Miller, 1992:178). In particular, it helps to enhance the external validity of the study, which refers to the extent to which the results of one study can be applied to other situations. In this study, it was reflected in the detailed background information provided about the conceptualisation of the GBV module. An audit trail 
was provided as the research design and method were described in detail.

\section{Ethical considerations}

Students were briefed about the philosophy of servicelearning and informed that the reflective journals, the project reports and the focus group would be used for research purposes and only those who consented submitted their journals for inclusion in the study. The students were given a choice to participate in the focus group and were ensured that anonymity and confidentiality would be maintained throughout the reporting process (Patton, 1990:213). Personal identifiable information was substituted by a coding system (see text for anecdotal referencing). The researcher thus took into account the rights of the participants to self-determination, to full disclosure and not to be harmed. Permission to conduct the research was sought from the Ethical Committee of the Faculty of Health Sciences, UWC.

\section{OUTCOMES}

Five possible cognitive and affective factors determine the success of a service-learning programme namely personal, interpersonal development, perspective transformation, citizenship skills and values (Eyler \& Giles, 1999:24). These factors represent a conceptual framework for the analysis.

It was evident that the students' engagements in the various activities led to the integration of their theoretical knowledge through active participation in a practical setting. Sternas et al. (1999:67) and Sedlack et al. (2003:99) assert that service-learning experiences benefit students by enhancing their knowledge and communication skills, strengthening their critical thinking abilities and problem solving skills in a group. This was apparent in the themes that emerged during the focusgroup discussions and in their reflective journals. The following themes were identified; the development of professional skills and competencies; the integration of theory and practice; collaborative efforts and partnership; and critical learning experience through reflection and civic engagement.

\section{Students' service-learning experiences}

\section{Development of professional skills and competencies}

Transformation in South Africa has impacted on the workplace resulting in a constant process of change, and professional training should prepare students to work within this dynamic environment. It is essential for students to develop the ability to improvise and utilise their initiative in real situations where logistics are minimal. "I was feeling excited because for the first time in my training l'm going to be in charge of something. There would be no sister instructing me to do this and that".

"We were always talking about improvising, but when there is equipment like in the hospital, it is not as difficult'. Students should also be able to facilitate change and exercise flexibility in their management of changing situations. "I experienced how it is to be thrown in the deep end you have to swim your way out'. The service-learning experience therefore served as a catalyst or medium for transformation in the students (Weisskirch, 2003:142).

The nursing students found the learning experience and the process of learning valuable, even if the planned outcomes did not always occur. "I personally feel that the placement will help me grow professionally and as a person".

They perceived the need for flexibility in their approach, amidst unstructured scheduling and logistics. The students therefore recognised how service-learning allowed them to explore beyond their usual notions of themselves (Weisskirch, 2003:144) as indicated in the following quote: "Despite the unstructuredness of the course, we feel our aims were adequately achieved".

There was also the added factor of this being the trial run of the course, which required additional flexibility and innovation to ensure success. This factor created unexpected opportunities for learning that developed throughout the process of implementation. "My concern was how we are going to be able to start providing services when our clinic has no equipment needed in order for the facility to function. However, we were able to save a choking child by applying the skills we've acquired throughout the training".

The process was, therefore, as important as the ex- 
pected outcomes. There was a connection between what they had learnt through the service-learning experience and what they had learnt theoretically in the classroom setting, especially with regard to the reality of the challenges involved in health service delivery. "It really was an eye-opener for me to be placed at $X$ because being a student in a clinic or hospital setting, you always wait [to hear] what the Sister is saying ... but here ... I realised you must be responsible ....".

It is clear from the students' experiences that communication was a vital skill needed during their placement. "We should enhance our communication skills because in our group, we did a lot of phoning around and a lot of interviews and things". Bradbard, Henton, Mize, Grover and Roberts (1999:18) corroborate the importance of communication when they assert that "communication is the key" and "we need to ensure that our communication is functioning in top form".

"One of my good outstanding experiences, the fact that at the beginning of the day we will come here, we will brainstorm, each group will have its frustrations and sometimes the arguments and after that we have some chat about things we didn't know about each other, just talking and laughing. That for me was good because um, since I have been in this class I haven't had a moment like that when people talk about their hopes for the future, so it gave me the time to learn more about people I have been around".

Students who participate in service-learning, have opportunities to apply classroom knowledge to communities and, in doing so, are enabled to build patient education and advocacy skills and to acquire the community competencies needed to practice in a changing health care environment (Sternas et al. 1999:67). It could be asserted that students learn, develop and benefit from relevant skills through active participation in organised service experiences. "The placement was a step for the future. I've learnt to be responsible because the lecturer was not always here; she came just to give advice".

The challenging real-life situations students were exposed to provided opportunities to learn, but also made the achievement of all the outcomes more difficult. Students were expected to reflect on the service-learning experience itself because "All group members had to compile a personal journal of their feelings and experiences during their placement" and to examine reasons why the outcomes may have been difficult to achieve. "Reflection is key for students in service-learning courses to link the concrete experience to more abstract learning" (Hatcher \& Bringle,1997 in Weisskirch, 2003:141). "Discussions with $X$ with regards to our objectives, changes were made and clarity around learning objectives was achieved at the end of the meeting". They also learned to take responsibility for their failures and successes. The failures were used as teachable moments to learn and make adjustments to curricula.

\section{Integration of theory and practice}

The success of service-learning can be defined in terms of how effective the transformative learning experiences have been for students during their clinical placement. This process is highly dependent on how well the service-learning internship is planned and organised in terms of management, supervision, assessment and reflection, and how it feeds back into the curriculum. Nursing educators must therefore develop opportunities for students that address community-driven initiatives and integrate real world experiences into nursing curricula (Evans, Helton \& Blackburn, in Hayward \& Weber, 2003:9).

"During this week we had our first incident. A woman fainted at the entrance of the clinic and the nurses were called to help. She seemed to be having a seizure. We provided a safe environment and first aid to the woman. We monitored her vital signs and when she was lucid, we referred and accompanied her to the nearest community health centre. I realised that whenever there will be a medical problem, people will naturally turn to us. This made me a bit nervous, as I didn't feel we were adequately equipped to handle all situations, as we barely had a first aid kit. I was a bit reassured by my colleagues that we could handle this as we had handled the previous situation okay, we would be fine".

This anecdote emphasised linking the service-learning experience with nursing theory, as students were required to reflect on the experience in a written journal. If educators wish to cultivate or maintain an interest in community-based nursing, there should be ample and early opportunities to experience this form of practice 
(Nehls \& Vandermause, 2004:83).

\section{Collaborative efforts and partnership}

The development of sustainable partnerships between the academic institution, the services sector and the community is enhanced by collaboration. When engaging in professional training, academics and academic institutions are expected to be ethically accountable. This implies that training, which involves working in the community and providing a service, needs to be sustainable when the students leave the community placement. To ensure sustainability, it is essential to enter into equitable partnerships with the community and the service providers, and to build capacity so that the service initiated by the students can be maintained once they withdraw. In order to promote civic responsibility, nursing is moving away from the acute-care setting to service learning in communities (Hayward \& Weber, 2003:6). Collaboration with community-based service providers and colleagues is thus essential in preparing students for nursing practice. "I learned how to work with different attitudes and people who are afraid of being delegated to and sharing responsibilities and things".

While working in a service-learning situation, students realised the opportunity for teamwork and this discouraged conflict and competition among individuals and partners. "... It really opened my eyes to see, that we can help each other and for me a real highlight is the fact that together we conquered all the things and now in the end you can actually just laugh at the things you were so angry about and when we felt like giving up and I think now we can say that it was worth the effort". Insight often comes when students reflect on their community experience; they recognise the paradox between the easy answers that come with superficial knowledge and the confusion that results from a deeper knowledge and experience.

This paradox comes as a revelation that either enhances their service or acts as a barrier that discourages them, depending on the extent of their intellectual development. "Another topic of frustration was our lecturer's inability to give us clear guidelines. It was frustrating to start something and then to change it mid-way because it was not according to standard. At times, I felt that this placement is a waste of precious time and effort". "I felt she is talking like that because she is never with us when we are doing our workshops" whilst others experienced "light-bulb moments: in this regard". "During our feedback sessions with Ms $X$, we realised how inexperienced we are at the actual interview. A beautiful learning experience".

Critical thinking that allows students to identify, frame, resolve and readdress social issues is dependent on both their knowledge and their level of cognitive development (Eyler \& Giles, 1999:100). "Finally everything was arranged and we could proceed with the interviews. We then realised why Ms $X$ put us through such a rigorous process to get there. Our level of comprehension is very different from the clients' and certain questions could evoke an emotional response that we could not adequately deal with. As researchers, we were still very inexperienced and needed a lot of guidance. We did not realise the consequences of administering the research tool at the time we started setting it up".

Professional preparation programmes in the health sciences cannot be relevant or effective unless the higher education institutions are responsive to the changing conditions of the communities around them and are able to collaborate with them (Gelmon, Holland, Siefer, Shinnamon \& Connors, 1998:98). This experience of service learning promoted skills in negotiation, as the students had to negotiate times for programmes and meetings. They acquired some skill in collaborating and came to appreciate that it requires time to meet, talk, plan and engage in decision-making. They gained knowledge about the different dimensions of the professional discipline of nursing and a deeper appreciation of the roles and responsibilities involved in being a health professional.

\section{Critical learning experience through reflec- tion}

By creating space for students to reflect on broader community involvement, they gain a sense of how their actions can matter and then tend to respond to this challenge. The frustration that students may experience in the real-life context develops their skills and abilities. As they serve the community, this learning process is further facilitated by the challenge and support that well-structured reflection provides (Eyler \& Giles, 1999:101).

"Two steps forward and three back. This week I was 
sick for two days and when I got back, the news hit me. We thought we were going to begin with our questionnaire, but ethics dictate that we need to have a questionnaire that all the clients understand. It feels like we are walking blindfolded and bumping into walls all the time. The best part of the week though was our feedback session with Ms $X$, when we explained our feelings of de-motivation, and I felt better afterward, as I understood the reasons for the seesaw, we felt we were on. Research is in its own way challenging but the groundwork can get boring at times".

Critical thinking in a service-learning situation for nursing students is a reasoning process that involves reflecting on ideas, actions and decisions (Sedlak et al. 2003:100). According to Sumner (1906), the education of people's critical faculty is the only education that makes good citizens, as individuals educated in it are not easily coerced, but rather seek out and weigh evidence. Paul (1993, in Sedlak et al. 2003:100) identifies three dimensions of critical thinking, namely elements of reasoning (identifying problems, identifying assumptions, developing multiple points of view and recognising consequences of actions), abilities of reasoning (raising questions, clarifying issues, generating solutions and evaluating actions), and traits of reasoning (affective attitudes including fair-mindedness, humility, courage, confidence and integrity). The responses from the students highlighted that the service-learning setting compelled them to assess the situation and its demands, and then apply their learning and skills to the meet these demands, which meant the students engaged in independent thinking. "When I had to assess the pregnant lady who fell from the stairs, I had to assess and refer and I had to design a kick chart for her to see if the foetus was still ok".

Students shared accountability with the service centre as well as the community for the goals and success of the project and this responsibility, knowledge and experience promoted trust and respect. The students' service-learning experience contributed to their professional development as they learnt to appreciate the transformative value of their knowledge and skills. " $M y$ outstanding experience was in this room, where I had to do a board meeting and at the end of the day it boosted my self-confidence so much".
Civic engagement changes the values of students and provides hope for a better future through collaboration. Civic engagement is initiated by being exposed to service-learning in the community and because of changes in values, active participation in democratic citizenship; informing the public about problems to be addressed and working toward solving problems that become part of students' professional activities. Institutions of higher learning have much to gain from community engagement through service-learning, including the intellectual challenge of applying scholarship to the pressing issues of the day and the accompanying prospect of new interdisciplinary insights. Furco (1996:11) asserts that community service is the engagement of students in activities that focus on the service being provided as well as the benefits these activities have for the recipients. The students in turn benefit by learning more about how their service makes a difference in the lives of the recipients and this can motivate them to become involved.

Service-learning provides a unique opportunity for students to internalise their knowledge and to recognise the value it has for the community and society. "It actually motivated me to go home where I came from and empower women who have been abused and tell them that it is okay to stand on your own and and stop whatever is happening to you because l've learned a lot from here".

Students become aware of the power of their own professional knowledge and abilities, which motivates them to engage in the processes of change and development. This is an empowering experience for young graduates and can contribute to the formation of their ethical basis and commitment to their profession (Daniels \& Adonis, 2003:4) as the following comments illustrate: "Once in a lifetime you receive the opportunity to be part of something great. Something so big that it makes you feel small, insignificant and scared. Yet, you know that the success of it depends on your contribution (how small it seems), as well as the contribution of others. You also realise that, due to its greatness and magnitude, a power higher than yourself is involved".

Service-learning thus exposes students to the needs of the larger society, engages them in addressing those needs through community service, and connects prac- 
tical experience to their theoretical knowledge.

\section{RECOMMENDATIONS}

The challenges of transformation necessitate innovative modes of learning, and service-learning experiences provide the intellectual, experiential and attitudinal challenges required to keep learning appropriate and relevant. The following recommendations, drawn from the experience of the students, provided feedback into the curriculum planning and implementation of the programme:

- Planning in terms of outcomes, time frames and available resources must be realistic in order to ensure effective implementation of the programme.

- The logistics linked to the implementation require the commitment and support of academic colleagues and the department.

- The signing of memoranda of agreements with the different partners provides a means of clarifying roles and responsibilities and can prevent the confusion that occurred at some stages of this trial run.

- Students should be carefully selected on the basis of their interest in gender-based violence, and their self-motivation and ability to work independently.

- The delivery of medical care is dependent on equipping a medical facility and the availability of a qualified primary health care practitioner employed by such a centre.

- Service-learning as a teaching methodology is successful in linking theory and practice and for developing professional skills and could be employed to meet the challenge of providing adequately trained health professionals.

\section{CONCLUSION}

The gender-based violence programme, CHESP, afforded students, through their service-learning experience, the opportunity to achieve goals defined by the community, services and the university in accordance with national policy. This programme also benefited the disenfranchised and marginalised community of survivors of domestic violence. Students came to understand the supportive roles that health professionals can play, and recognised that the development of the attributes of caring, advocacy and civic engagement is essential for their professional development. Comments in their reflective journals revealed that students valued their service-learning experience, and believed that this experience would expand into future collaborative relationships within civil society. The feedback on the service-learning experiences provided by the students, faculty and service provider has subsequently been utilised to revise the service-learning curriculum and to implement improved interventions to address challenges.

\section{REFERENCES}

ABRAHAMS, N; JEWKES, R \& LAUBSHER, R 1999: ‘I don’t believe in democracy in the home': Men's relationship with and abuse of women. Cape Town: CERSA(Women's Health), Medical Research Council.

AMERICAN ASSOCIATION OF COLLEGES OF NURSING (AACN) 1998: The essentials of baccalaureate education for professional nursing practice. Washington, DC: AACN.

BRADBARD, MR; HENTON, J; MIZE, J; GROVER, J \& ROBERTS, R 1999: Build it and they will come. (In: Chibucos, TR \& Lerner, RM eds 1999: The Birmingham Early Learning Center: Creating a vision for the future of Alabama's children. Service children and families through community-university partnership: Success stories. Springer: Kluwer Academic Publishers, pp13-19).

BRINK H 1996: Fundamentals of research methodology for health care professionals. Cape Town: Juta.

BRINGLE, R \& HATCHER, JA 1995: A service learning curriculum for faculty. Michigan Journal of Community Service Learning, Fall:112-122.

CAMPBELL, JC; PLISKA, MJ; TAYLOR, W \& SHERADIN, D 1994: Battered women's experiences in the emergency department. Journal of Emergency Nursing, 20:280-288.

CRABTREE, BF \& MILLER, WL 1992: Doing qualitative research. Thousand Oaks: Sage.

DEPARTMENT OF NATIONAL HEALTH \& THE SOUTH AFRICAN GENDER-BASED VIOLENCE AND HEALTH INITIATIVE 2001: Developing an appropriate health sector response to gender-based violence, Workshop Proceedings. Pretoria: SAGBVHI.

DANIELS, P \& ADONIS, T 2004: Service-learning in human ecology. Department of Human Ecology Newsletter, 7:10. Bellville: Printwize Consultants.

DANIELS, P \& ADONIS, T 2003: From hope to action, through knowledge: A case for service learning in human ecology. South African Association of Family Ecology and Consumer Sciences Newsletter, Gazette conference Edition. Belllville: Printwize Consultants. 
DEPARTMENT OF EDUCATION 1997: Higher Education Act 101 of 1977: As amended by the Higher Education Act 55 of 1999. Pretoria: Department of Education.

DEPARTMENT OF NATIONAL HEALTH 1997: White Paper on the transformation of the health system in South Africa [Online]. Available: http://www.doh.gov.za/docs/policy-f.html. (Accessed: August 2004).

DEPARTMENT OF NURSING UWC 2003: Management for genderbased violence module descriptor. Cape Town: University of the Western Cape, Faculty of Community and Health Sciences.

ELS, RC 2002: Saartjie Baartman Centre for Abused Women and Children: External evaluation report commissioned by the Department of Social Services (PAWC) and the Management Board of the Saartjie Baartman Centre for Women and Children. Athlone: Saartjie Baartman Centre.

EVANS, GW; HELTON, SM \& BLACKBURN, LS 2001: Students go to court: Experiential learning about domestic violence, (In: Hayward, KS \& Weber, I 2003: A community partnership to prepare nursing students to respond to domestic violence. Nursing Forum, 38(3):5-10).

EYLER, J \& GILES, D 1999: Where's the learning in service learning? San Francisco: Jossey-Bass.

FURCO, A 1996: Service learning: A balanced approach to experiential education. (In: Introduction to service learning toolkit. Providence: Campus Compact).

GELMON, SB; HOLLAND, BA; SEIFER, SD; SHINNAMON, AF \& CONNORS, K 1998: Community-university partnerships for mutual learning. Michigan Journal of Community Service Learning, Fall:97-107.

HAYWARD, KS \& WEBER, L 2003: A community partnership to prepare nursing students to respond to domestic violence. Nursing Forum, 38(3):5-10.

HEISE, L; ELLSBERG, M \& GOTTEMOELLET, M 1999: Ending violence against women. Population Reports, 27(4), Population Information Program, Center for Communication Programs, John Hopkins University, School of Public Health.

HEISE, L; RAIKES, A; WATTS, C \& ZWI, B 1994: Violence against women: A neglected public health issue in less developed countries. Soc Sci Med, 39(9):1165-1179.

JACOBY, B 1999: Partnerships for service learning. New Directions for Student Services, 87:19-35.

JULIE, H 2003: Chesp pilot service-learning courses narrative report: Management of gender-based violence 2003. Unpublished report. Cape Town: UWC CHESP Office.

JULIE, H 2005: Community-based service-learning through reflective practice. Cape Town: University of the Western Cape. (Unpublished MCur thesis).

JOINT EDUCATION TRUST 2004: Quality management of community engagement in higher education: A good practice guide for higher education institutions. Muizenburg: Joint Education Trust. KERNIC, MA; WOLF, M \& HOLT, V 2000: Rates and relative risk of hospital admission among women in violent intimate partner relationships. American Journal of Public Health, 90(9):1416. KISTNER, U 2003: Gender-based violence and HIV/AIDS in South Africa: A literature review. Johannesburg: Centre for AIDS Development, Research and Evaluation (CADRE) Department of Health. LEEDY, PD 1997: Practical research planning and design. New York: Prentice-Hall.

LEVY, K \& LEHNA, C 2002: A service-oriented teaching and learning project. Paediatric Nursing, 22(3):219-221.

LIMANDRI, BJ \& TILDEN VP 1996: Nurses' reasoning in the assessment of family violence. IMAGE: Journal of Nursing Scholarship, 28(3):247-252.

LONG, AB; LARSEN, P; HUSSEY, L \& TRAVIS, S 2001: Organising, managing and evaluating service learning projects. Educational Gerontology, 27(1):3-21.

MARSHALL, C \& ROSSMAN, CB 1989: Designing qualitative research. London: Sage.

MATTHEWS, S; ABRAHAMS, N; MARTIN, LJ; VETTEN, L; VAN DER MERWE, L \& JEWKES, R 2004: Every six hours: A national study of female homicide in South Africa [Online] MRC Policy Brief: MRC. [Available] http://www.mrc.ac.za/pressreleases/2004/ 11pres2004.htm. (Accessed: September 2004).

MERRIAM, SB 1998: Qualitative research and case study applications in education. San Francisco: Jossey Bass.

MOUTON, J 1996: Understanding social research. Pretoria: Van Schaik.

MOUTON, J; WILDSCHUT, L \& BOSHOFF, N 2004: A report on the CHESP Module Reports and Generic Questionnaire submitted to CHESP by the Evaluation Research Agency. Muizenburg: Joint Education Trust.

NEHLS, N \& VANDERMAUSE, R 2004: Community-driven nursing: Transforming nursing curricula and instruction. Nursing Education Perspectives, 25(2):81-85.

NUDELMAN, J \& TRIAS, HR 1999: Building bridges between domestic violence advocates and health care providers: Building comprehensive solutions to domestic violence (Publication \#6) [Online] http://www.VAW.umn.edu/Final Documents/bridges.asp. (Accessed: September 2004).

PATTON, MQ 1990: Qualitative evaluation and research methods. Newbury Park: Sage.

REDDY, T 2004: Higher education and social transformation: South Africa case study. Pretoria: Council on Higher Education.

SEDLAK, CA; O' DOHENY, M; PANTHOFFER, N \& ANAYA, E 2003: Critical thinking in students' service learning experiences. College Teaching, 51(3):99-103.

STERNAS, KA; O'HARE, P; LEHMAN, K \& MILLIGAN, R 1999: Nursing and medical student teaming for service learning in partner- 
ship with the community: An emerging holistic model for interdisciplinary education and practice. Holistic Nursing Practice, 13(2):66-77.

STRAUSS, AL \& CORBIN, J 1990: Basics of qualitative research: grounded theory procedures and techniques. Thousand Oaks: Sage.

SUMNER, WG 1906: What is critical thinking? http:// www.criticalthinking.org/university/univlibdir.html. Accessed: 15 June 2004.

UNITED NATIONS GENERALASSEMBLY 1993: Declaration on the elimination of violence against women. Proceedings of the $85^{\text {th }}$ Plenary Meeting, Geneva, 20 December 1993.

WATTS, C \& ZIMMERMAN, C 2002: Violence against women: global scope and magnitude. Lancet, 359:1232-37.

WEIGERT, KM 1998: Academic service learning: Its meaning and relevance. New Directions for Teaching and Learning, (73) Spring :3-10.

WEISSKIRCH, RS 2003: Analyzing student journal in a servicelearning course. Academic Exchange, Summer:141-145 WELLINGTON, B \& AUSTIN, P 1996: Orientations to reflective practice. Educational Research, 38(3):307-316.

WILLIAMS, LS 1995: Failure to pursue indications of spousal abuse could lead to tragedy, physicians warned. Canadian Medical Association Journal, 152:1488-1491.

ZLOTKOWSKI, E 1998: A new model of excellence. (In: Zlotkowski, E ed 1998: Successful service-learning programs: New models of excellence in higher education. Bolton: Anker. 